\title{
PENANDA DAN MAKNA ADVERBIA PADA KUMPULAN CERPEN BEDAK DALAM PASIR KARYA SULE SUBAWEH
}

\section{MARKERS AND THE MEANING OF ADVERBIA IN THE COLLECTION OF SHELL PACTS IN THE SAND OF SULE SUBAWEH}

\author{
${ }^{1}$ Gita Safria Dwi Ratna, ${ }^{2}$ Sudarmini \\ Universitas Ahmad Dahlan \\ 1' $\underline{\text { Safriagita@yahoo.com, }{ }^{2} \text { sudarminiak@gmail.com }}$
}

\begin{abstract}
Abstrak
Adverbia merupakan kata yang menjelaskan verba, adjektiva, atau adverbia lain, pada tataran frasa. Selain itu, adverbia juga dapat mewatasi fungsi sintaksis. Penelitian tentang adverbia cenderung belum banyak yang meneliti. Penelitian ini dikaji mengenai adverbia derajat dan adverbia penjumlahan pada kumpulan cerpen Bedak dalam Pasir karya Sule Subaweh. Tujuan penelitian ini adalah (1) mendeskripsikan penanda adverbia pada kumpulan cerpen Bedak dalam Pasir karya Sule Subaweh; (2) mendeskripsikan makna penanda adverbia derajat dan adverbia penjumlahan pada Kumpulan Cerpen Bedak dalam Pasir karya Sule Subaweh. Metode penelitian ini dilakukan dengan metode baca dan teknik catat. metode analisis data yang dilakukan adalah metode agih. Hasil penelitian ini adalah sebagai berikut: (1) penanda adverbia derajat dan adverbia penjumlahan pada Kumpulan Cerpen Bedak dalam Pasir karya Sule Subaweh; (2) makna penanda adverbia derajat dan adverbia penjumlahan pada Kumpulan Cerpen Bedak dalam Pasir karya Sule Subaweh.
\end{abstract}

Kata Kunci: Adverbia, Penanda, Makna.

\begin{abstract}
Adverb is a word that describes a verb, adjective, or other adverb, at the level of a phrase. In addition, adverbs can also limit syntactic functions. There is little research about adverbial research. This study examined the degree of adverb and addition adverb in the collection of short stories Powder in the Sand by Sule Subaweh. The purpose of this study is (1) to describe the adverb markers in the collection of short stories Powder in the Sand by Sule Subaweh; (2) describe the meaning of the degree adverb markers and the addition adverb in the Short Story Powder in the Sand Collection by Sule Subaweh. The research method was carried out by reading and note taking methods. the data analysis method used is the method of distribution. The results of this study are as follows: (1) degree adverb markers and addition adverbs in the Powder Short Story Collection in Sand by Sule Subaweh; (2) the meaning of degree adverb markers and addition adverb in the Short Story Powder Collection in the Sand by Sule Subaweh.
\end{abstract}

Keywords: Adverb, Markers, Meanings.

\section{PENDAHULUAN}

Adverbia termasuk ke dalam kelas kata tertutup, pengertian adverbia dapat dipahami sebagai kategori yang mendampingi nomina, verba, dan ajektiva dalam pembentukan frasa atau dalam pembentukan klausa. Adverbia juga bisa sebagai pendamping kelas terbuka yang membentuk sebuah frase untuk mengisi salah satu fungsi sintaksis. Adverbia juga dapat menjelaskan pronomina dan numeralia karena memiliki keterkaitan yang sangat erat dengan 
nomina. Adverbia juga menjelaskan fungsi-fungsi sintaksis yang umumnya berfungsi sebagai predikat, pada tataran klausa.

Menurut Chaer (2015: 49) adverbia adalah kategori yang mendampingi nomina, verba, dan ajektiva dalam pembentukan frase; atau dalam pembentukan klausa. Penelitian ini akan dikaji mengenai adverbia derajat dan adverbia penjumlahan. Adverbia derajat (kualitas) adalah adverbia yang menyatakan tingkatan mutu keadaan atau kegiatan. Penanda adverbia derajat antara lain yaitu sangat, amat, sekali, paling, lebih, cukup, kurang, agak, hampir, rada, maha, nian, dan terlalu (Chaer, 2010: 54). Menurut Chaer (2010: 52) adverbia penjumlahan adalah adverbia yang menyatakan 'banyak' atau 'kualitas' terhadap kategori yang didampingi. Penanda adverbia penjumlahan yaitu banyak, sedikit, beberapa, semua, seluruh, sejumlah, separuh, setengah, kira-kira, sekitar, dan kurang lebih (Sudarmini, 2017: 256). Tujuan penelitian ini adalah untuk mendeskripsikan penanda adverbia derajat dan penjumlahan pada kumpulan cerpen Bedak dalam Pasir karya Sule Subaweh dan mendeskrikpsikan fungsi klausa yang diduduki adverbia derajat dan adverbia penjumlahan pada kumpulan cerpen Bedak dalam Pasir karya 1,15. Bila menyertakan gambar, foto, dan tabel, diberi judul, nomor, dan keterangan lengkap Sule Subaweh. Penelitian yang relevan dengan penelitian ini adalah tesis karya Sudarmini yang dimuat di http://eprints.ums.ac.id/id/eprint/53179 Universitas Muhammadiyah Surakarta pada 12 Juli 2017 dengan judul "Adverbia Aspek, Sangkalan, dan Jumlah dalam Teks Terjemahan Alquran: Kajian Fungsi dan Kategori”. Persamaan pada penelitian ini adalah pada objeknya yaitu adverbia. Perbedaan penelitian ini terletak pada objeknya yaitu penelitian karya Sudarmini tersebut membahas mengenai adverbia aspek, sangkalan, dan jumlah pada teks terjemahan Alquran, sedangkan penelitian ini yaitu penanda dan makna adverbia derajat dan adverbia penjumlahan pada kumpulan cerpen Bedak dalam Pasir karya Sule Subaweh.

\section{METODE PENELITIAN}

Penelitian ini termasuk ke dalam jenis penelitian deskriptif kualitatif. Penelitian deskriptif adalah penelitian yang bertujuan menjelaskan fenomena yang ada dengan menggunakan angka-angka unutk mencandrakan karakteristik atau kelompok. Data pada penelitian ini adalah satuan lingual yang menandakan penanda adverbia derajat dan adverbia penjumlahan pada kumpulan cerpen Bedak dalam Pasir karya Sule Subaweh. Sumber data penelitian ini adalah kumpulan cerpen Bedak dalam Pasir karya Sule Subaweh. Teknik pengumpulan data yang dilakukan pada penelitian ini adalah teknik catat dengan mentode baca. Dikatakan metode baca karena untuk mengumpulkan data, peneliti membaca keseluruhan isi cerpen. Selanjutnya, dikatakan teknik catat karena setelah membaca dan menemukan klausa yang mengandung adverbia derajat dan adverbia penjumlahan, peneliti mencatat untuk dijadikan data. Metode analisis data yang digunakan adalah metode agih. Metode agih adalah alat penentunya bagian dari bahasa yang bersangkutan itu sendiri (Sudaryanto, 2015: 15). Teknik dasar metode agih adalah teknik bagi unsur langsung atau teknik BUL. Teknik BUL bekerja dengan cara membagi satuan lingual datanya menjadi beberapa bagian atau unsur, dan unsur yang bersangkutan dipandang sebagai bagian yang langsung membentuk satuan lingual yang dimaksud (Sudaryanto, 2015: 37). 


\section{HASIL DAN PEMBAHASAN}

Hasil penelitian ini yaitu penanda adverbia derajat dan penjumlahan pada kumpulan cerpen Bedak dalam Pasir karya Sule Subaweh dan makna adverbia derajat dan penjumlahan pada kumpulan cerpen Bedak dalam Pasir karya Sule Subaweh.

Tabel 1Penanda Adverbia Derajat

pada Kumpulan Cerpen Bedak dalam Pasir Karya Sule Subaweh

\begin{tabular}{ccc}
\hline No. & Penanda & Frekuensi \\
\hline 1. & sangat & 16 \\
\hline 2. & paling & 4 \\
\hline 3. & hampir & 8 \\
\hline 4. & sekali & 7 \\
\hline 5. & cukup & 4 \\
\hline 6. & lebih & 15 \\
\hline 7. & terlalu & 1 \\
\hline
\end{tabular}

Tabel 2 Penanda Adverbia Penjumlahan

pada Kumpulan Cerpen Bedak dalam Pasir Karya Sule Subaweh

\begin{tabular}{ccc}
\hline No. & Penanda & Frekuensi \\
\hline 1. & beberapa & 26 \\
\hline 2. & banyak & 4 \\
\hline 3. & sedikit & 12 \\
\hline 4. & seluruh & 3 \\
\hline 5. & semua & 6 \\
\hline 6. & separuh & 2 \\
\hline 7. & setengah & 3 \\
\hline 8. & sekali & 1 \\
\hline
\end{tabular}

Tabel 1 dan 2 berisi penanda adverbia derajat dan adverbia penjumlahan disertai frekuensi data yang ditemukan untuk mendukung dalam memahami hasil dari peneltian pertama.

Berdasarkan hasil penelitian yang telah dilakukan, maka berikut ini akan dijelaskan mengenai pembahasan mengenai penanda dan makna adverbia derajat dan adverbia penjumlahan pada kumpulan cerpen Bedak dalam Pasir karya Sule Subaweh.

Penanda Adverbia Derajat dan Adverbia Penjumlahan pada Kumpulan Cerpen Bedak dalam Pasir karya Sule Subaweh

\section{a. Adverbia Derajat}

Data adverbia derajat yang ditemukan pada kumpulan cerpen Bedak dalam Pasir karya Sule Subaweh ini memiliki penanda yaitu sangat, paling, hampir, sekali, sangat, cukup, dan 
terlalu. Pembahasan mengenai penanda adverbia derajat pada kumpulan cerpen Bedak dalam Pasir karya Sule Subaweh adalah sebagai berikut.

1) Penanda sangat

(1) Mungkin ia sangat menyesal.

(2) Dia juga sangat senang dengan cerita-cerita para nabi.

(3) Ia sadar hanya itu yang sangat realistis.

Penanda sangat ditemukan sebanyak 16 penanda dari data yang dikumpulkan. Biasanya penanda sangat diikuti oleh verba, nomina, adverbia dan yang paling banyak diikuti oleh adjektiva.

2) Penanda paling

(4) Yang paling dia suka adalah kisah nabi Yusuf.

(5) Ada yang paling murah.

(6) Paling tidak satu bulan dan tentu harus rutin melakukannya.

Penanda paling ditemukan sebanyak 4 penanda dari data yang dikumpulkan. Biasanya penanda paling diikuti oleh verba, nomina, numeralia dan adjektiva. Penanda paling menduduki fungsi subjek dan predikat.

3) Penanda hampir

(7) Hampir setiap hari dia menggerak-gerakkan tangannya.

(8) Hampir setiap waktu ia selfie dan mengedit foto.

(9) Hampir setiap minggu saya keluar kota, menawarkan brosur ini.

Penanda hampir ditemukan sebanyak 8 penanda dari data yang dikumpulkan. Biasanya penanda hampir diikuti oleh verba, nomina, dan numeralia. Penanda hampir menduduki fungsi predikat dan keterangan.

4) Penanda sekali

(10) Awalnya dia mengidolakan guru bahasa Indonesia yang suka sekali bercerita.

(11) Syarif suka sekali dengan sastra dan tokoh-tokoh besar revolusioner.

(12) Aku sama sekali tidak tahu.

Penanda sekali ditemukan sebanyak 7 penanda dari data yang dikumpulkan. Biasanya penanda sekali diikuti oleh verba, nomina, adverbia, dan adjektiva . Penanda sekali menduduki fungsi predikat dan keterangan.

5) Penanda cukup

(13) Selain biayanya cukup mahal, suntik vitamin juga bersifat sementara.

(14) HP itu cukup ampuh untuk memikat hati suaminya.

(15) DP-nya cukup lima juta saja.

Penanda cukup ditemukan sebanyak 4 penanda dari data yang dikumpulkan. Biasanya penanda cukup diikuti oleh verba, numeralia, dan adjektiva. Penanda cukup menduduki fungsi subjek dan predikat.

6) Penanda terlalu

(16) Mungkin terlalu sering KB.

Penanda terlalu ditemukan sebanyak 1 penanda dari data yang dikumpulkan. Penanda cukup diikuti adjektiva . Penanda cukup menduduki fungsi predikat. 


\section{b. Adverbia Penjumlahan}

Data adverbia penjumlahan yang ditemukan pada kumpulan cerpen Bedak dalam Pasir karya Sule Subaweh ini memiliki yaitu beberapa, banyak, sedikit, separuh, setengah, semua, sekali, seluruh, dan banyak. Pembahasan mengenai penanda adverbia derajat pada kumpulan cerpen Bedak dalam Pasir karya Sule Subaweh adalah sebagai berikut.

1) Penanda beberapa

(17) Beberapa minggu terakhir, syarif tidur dalam jangka waktu tak wajar.

(18) Beberapa tokoh idolanya dilukis kemudian ditempel di dinding kamarnya.

(19) Saya baca mungkin surah Yasin dan beberapa surah juz amma.

Penanda beberapa ditemukan sebanyak 26 penanda dari data yang dikumpulkan. Penanda ini merupakan penanda yang paling banyak ditemukan. Biasanya penanda beberapa diikuti oleh adverbia dan paling banyak diikuti oleh nomina. Penanda beberapa menduduki fungsi subjek, predikat, dan keterangan.

2) Penanda banyak

(20) Ia pun mengikuti saranku, banyak menghabiskan waktu di dalam kamar.

(21) Istriku terpaksa berangkat sendiri karena aku banyak pekerjaan di kantor.

(22) Perempuan itu juga banyak mengajarkan berbagai hal kepadanya

Penanda banyak ditemukan sebanyak 4 penanda dari data yang dikumpulkan. Biasanya penanda banyak diikuti oleh verba dan nomina. Penanda banyak hanya menduduki fungsi predikat.

3) Penanda sedikit

(23) Suprian yang sedikit memaksakan tersenyum.

(24) Langkah kaki ragu-ragu ke kerumunan di pagar pembatas yang kini tinggal sedikit itu.

(25) Tapi semangatnya untuk meyakinkanku tak sedikit pun surut.

Penanda sedikit ditemukan sebanyak 12 penanda dari data yang dikumpulkan. Biasanya penanda sedikit diikuti oleh nomina, verba, adjektiva, dan ada juga yang diikuti partikel. Penanda sedikit menduduki fungsi subjek, predikat, dan keterangan.

4) Penanda separub

(26) Ia julurkan separuh lidah dan memajukan bibir.

(27) Separuh tubuhnya terbingkai jendela.

Penanda separuh ditemukan sebanyak 2 penanda dari data yang dikumpulkan. Biasanya penanda separuh hanya diikuti oleh nomina. Penanda separuh menduduki fungsi subjek dan keterangan.

5) Penanda setengah

(28) Setengah jam sebelum jadwa pesawat yang ditumpangi suaminya.

(29) DP-nya tiga setengah juta.

(30) Jam setengah enam tentu orang-orang masih belum banyak yang bangun.

Penanda setengah ditemukan sebanyak 3 penanda dari data yang dikumpulkan. Biasanya penanda setengah diikuti oleh nomina dan numeralia. Penanda setengah menduduki fungsi predikat, dan keterangan.

6) Penanda semua

(31) Buku dongeng hampir sudah diceritakan semua. 
(32) Orang yang membiayai semua kebutuhan dan uang sekolahku sampai kuliah.

(33) Semua orang akan mengalami apa yang kau alami.

Penanda semua ditemukan sebanyak 6 penanda dari data yang dikumpulkan. Biasanya penanda semua diikuti oleh nomina dan adverbia. Penanda semua menduduki fungsi subjek, predikat, objek, dan keterangan.

7) Penanda seluruh

(34) Aku tidak menjawab, hanya memeluknya penuh seluruh.

(35) Seluruh tubuhnya gemetar.

Penanda seluruh ditemukan sebanyak 3 penanda dari data yang dikumpulkan. Biasanya penanda seluruh diikuti oleh nomina dan adverbia.

\section{Makna adverbia derajat dan adverbia penjumlahan pada kumpulan cerpen Bedak dalam Pasir karya Sule Subaweh}

\section{a. Adverbia Derajat}

Data adverbia derajat yang ditemukan pada kumpulan cerpen Bedak dalam Pasir karya Sule Subaweh ini memiliki penanda yaitu sangat, paling, hampir, sekali, sangat, cukup, dan terlalu. Masing-masing penanda tersebut memiliki makna untuk menjelaskan maksud dari klausanya. Pembahasan mengenai penanda adverbia derajat pada kumpulan cerpen Bedak dalam Pasir karya Sule Subaweh adalah sebagai berikut.

1) Penanda sangat

(36) Mungkin ia sangat menyesal.

(37) Dia juga sangat senang dengan cerita-cerita para nabi.

(38) Ia sadar hanya itu yang sangat realistis.

Penanda sangat sebagai penanda adverbia derajat memiliki makna yaitu untuk menyatakan suatu keadaan tidak ada yang melebihi tarafnya atau derajatnya.

2) Penanda paling

(39) Yang paling dia suka adalah kisah nabi Yusuf.

(40) Ada yang paling murah.

(41) Paling tidak satu bulan dan tentu harus rutin melakukannya.

Penanda paling sebagai penanda adverbia derajat memiliki makna yaitu untuk menyatakan tindakan yang tertinggi derajat penilaiannya.

3) Penanda hampir

(42) Hampir setiap hari dia menggerak-gerakkan tangannya.

(43) Hampir setiap waktu ia selfie dan mengedit foto.

(44) Hampir setiap minggu saya keluar kota, menawarkan brosur ini.

Penanda hampir penanda adverbia derajat memiliki makna yaitu untuk menyatakan keadaan yang sebenarnya.

4) Penanda sekali

(45) Awalnya dia mengidolakan guru bahasa Indonesia yang suka sekali bercerita.

(46) Syarif suka sekali dengan sastra dan tokoh-tokoh besar revolusioner.

(47) Aku sama sekali tidak tahu. 
Penanda sekali sebagai penanda adverbia derajat memiliki makna yaitu untuk menyatakan keadaan yang bertaraf tinggi atau utama.

5) Penanda cukup

(48) Selain biayanya cukup mahal, suntik vitamin juga bersifat sementara.

(49) HP itu cukup ampuh untuk memikat hati suaminya.

(50) DP-nya cukup lima juta saja.

Penanda cukup sebagai penanda adverbia derajat memiliki makna yaitu untuk menyatakan keadaan yang memadai derajatnya.

6) Penanda terlalu

(51) Mungkin terlalu sering KB.

Penanda terlalu merupakan sebagai penanda adverbia derajat memiliki makna yaitu untuk menyatakan keadaan yang melebihi seharusnya. Penanda ini merupakan penanda yang paling sedikit ditemukan.

\section{b. Adverbia Penjumlahan}

Data adverbia penjumlahan yang ditemukan pada kumpulan cerpen Bedak dalam Pasir karya Sule Subaweh ini memiliki yaitu beberapa, banyak, sedikit, separuh, setengah, semua, sekali, seluruh, dan banyak. Masing-masing penanda tersebut memiliki makna untuk menjelaskan maksud dari klausanya. Pembahasan mengenai penanda adverbia derajat pada kumpulan cerpen Bedak dalam Pasir karya Sule Subaweh adalah sebagai berikut.

1) Penanda beberapa

(52) Beberapa minggu terakhir, syarif tidur dalam jangka waktu tak wajar.

(53) Beberapa tokoh idolanya dilukis kemudian ditempel di dinding kamarnya.

(54) Saya baca mungkin surah Yasin dan beberapa surah juz amma.

Penanda beberapa sebagai penanda adverbia derajat memiliki makna yaitu untuk menyatakan jumlah yang tidak banyak. Penanda ini merupakan penanda yang paling banyak ditemukan.

2) Penanda banyak

(55) Ia pun mengikuti saranku, banyak menghabiskan waktu di dalam kamar.

(56) Istriku terpaksa berangkat sendiri karena aku banyak pekerjaan di kantor.

(57) Perempuan itu juga banyak mengajarkan berbagai hal kepadanya

Penanda banyak sebagai penanda adverbia derajat memiliki makna yaitu untuk menyatakan jumlah yang lebih.

3) Penanda sedikit

(58) Suprian yang sedikit memaksakan tersenyum.

(59) Langkah kaki ragu-ragu ke kerumunan di pagar pembatas yang kini tinggal sedikit itu.

(60) Tapi semangatnya untuk meyakinkanku tak sedikit pun surut.

Penanda sedikit sebagai penanda adverbia derajat memiliki makna yaitu untuk menyatakan keadaan yang bertaraf tinggi atau utama.

4) Penanda separub

(61) Ia julurkan separuh lidah dan memajukan bibir.

(62) Separuh tubuhnya terbingkai jendela. 
Penanda separuh sebagai penanda adverbia derajat memiliki makna yaitu untuk menyatakan jumlah seperdua dari keseluruhan. Penanda ini bisa saling menggantikan dengan penanda setengah karena memiliki persamaan pada maknanya.

5) Penanda setengah

(63) Setengah jam sebelum jadwa pesawat yang ditumpangi suaminya.

(64) DP-nya tiga setengah juta.

(65) Jam setengah enam tentu orang-orang masih belum banyak yang bangun.

Penanda setengah sebagai penanda adverbia derajat memiliki makna yaitu untuk menyatakan seperdua dari keseluruhan. Penanda ini bisa saling menggantikan dengan penanda separuh karena memiliki persamaan pada maknanya..

6) Penanda semua

(66) Buku dongeng hampir sudah diceritakan semua.

(67) Orang yang membiayai semua kebutuhan dan uang sekolahku sampai kuliah.

(68) Semua orang akan mengalami apa yang kau alami.

Penanda semua sebagai penanda adverbia derajat memiliki makna yaitu untuk menyatakan tidak ada kecuali. Penanda ini bisa saling menggantikan dengan penanda seluruh karena memiliki persamaan pada maknanya.

7) Penanda selurub

(69) Aku tidak menjawab, hanya memeluknya penuh seluruh.

(70) Seluruh tubuhnya gemetar.

Penanda seluruh sebagai penanda adverbia derajat memiliki makna yaitu untuk menyatakan tidak ada kecuali. Penanda ini bisa saling menggantikan dengan penanda semua karena memiliki persamaan pada maknanya.

\section{SIMPULAN}

Berdasarkan hasil penelitian dan pembahasan yang telah dijelaskan di bab sebelumnya, maka dapat diperoleh kesimpulan yaitu penanda adverbia derajat yang ditemukan yaitu lebih, sangat, paling, hampir, sekali, sangat, cukup, dan terlalu. Paling banyak ditemukan penanda sangat yaitu sebanyak 16 kata dan paling sedikit yaitu penanda terlalu sebanyak satu kata. Selanjutnya, ditemukan penanda adverbia penjumlahan antara lain yaitu beberapa, banyak, sedikit, separuh, setengah, semua, sekali, seluruh, dan banyak. Penanda yang paling banyak ditemukan yaitu beberapa sebanyak 26 kata dan paling sedikit yaitu sekali sebanyak satu kata. Makna adverbia derajat menyatakan tingkat atau taraf atau derajat dari suatu keadaan. Berbeda dengan adverbia derajat, adverbia penjumlahan memiliki makna yang menyatakan sebagian ditandai dengan penanda sebagian, setengah, banyak, sedikit, beberapa, dan separuh, dan yang menyatakan keseluruhan ditandai dengan penanda selurub dan semua.

\section{DAFTAR PUSTAKA}

Chaer, A. 2015. Sintaksis Bahasa Indonesia (Pendekatan Proses). Jakarta: Rineka Cipta.

Najihah, M. 2017. "Jenis dan Penanda Adverbia Aspek pada Teks Terjemahan Alquran yang Mengandung Etika Berbahasa", Tesis. Surakarta: Universitas Muhammadiyah 
Surakarta. https://publikasiilmiah.ums.ac.id/xmlui/handle/11617/8918. Diakses pada Rabu, 20 Maret 2019.

Nusarini. 2017. "Adverbia dalam Bahasa Indonesia: Tinjauan Bentuk dan Perilaku Semantisnya", Vol. 2, No. 3. Hlm 37. Jurnal Gramatika: Penelitian Pendidikan, Bahasa, dan Sastra Indonesia. http://www.jurnal.ustjogja.ac.id/index.php/caraka/articel/view/1889 Diakses pada Rabu, 20 Maret 2019.

Markhamah. 2013. Ragam analisis kalimat bahasa Indonesia. Surakarta: Muhammadiyah University Press.

Ramlan, M. 1986. Ilmu Bahasa Indonesia Sintaksis. Yogyakarta: CV Karyono.

Sudaryanto. 2015. Metode Aneka Teknik Analisis Bahasa. Yogyakarta: Universitas Sanata Dharma APPTI.

Sudarmini. 2017. “Adverbia Aspek, Sangkalan, dan Jumlah dalam Teks Terjemahan Alquran: Kajian Fungsi dan Kategori”. Tesis. Surakarta: Universitas Muhammadiyah Surakarta. http://eprints.ums.ac.id/id/eprint/53179 Diakses pada Rabu, 20 Maret 2019.

Sudarmini. 2017. "Adverbia Jumlah dalam Teks Terjemahan Alquran: Kajian Fungsi dan Kategori”. Vol 1, No 1. Hlm. 256. Seminar Nasional: Universitas Sriwijaya. http://conference.unsri.ac.id/index.php/SNBI/article/view/519 Diakses pada Rabu, 20 Maret 2019.

Sugiyono. 2018. Metode Penelitian Kuantitatif, Kualitatif, dan R\&D. Bandung: PT. Alfabeta.

Wiyadi, M. 2017. "Makna Adverbia Penanda Aspek, Sangkalan, dan Jumlah Pada Teks Terjemahan Alquran (T'TA)". Tesis. Surakarta: Universitas Muhammadiyah Surakarta. https://publikasiilmiah.ums.ac.id/xmlui/handle/11617/8909 